\title{
Assessment of the nutritional quality of proteins: the use of 'ileal' digestibilities of amino acids as measures of their availabilities*
}

\author{
BY S. C. ACHINEWHU† AND D. HEWITT \\ National Institute for Research in Dairying, \\ Shinfield, Reading RG2 $9 A T$
}

(Received 25 February 1977 - Accepted 3 November 1978)

1. A comparative study was made of two biological techniques for assessing protein quality in wheat and barley, and in a soya-bean-protein isolate both as received, and after being heat-damaged by autoclaving. Amino acid digestibility was determined by the 'ileal' analysis technique while amino acid availability was measured in growth assays. Some chemical and microbiological tests were also done.

2. Heat treatment of the soya-bean-protein isolate caused little change in amino acid composition but the digestibility of all amino acids and the availability of lysine and methionine were severely reduced, lysine being most affected. The reduced availability of lysine was not entirely attributable to impaired digestibility.

3. The amino acids in wheat and barley were highly digestible. The availability of methionine and lysine in barley and of methionine in wheat was high, whereas the availability of lysine in wheat was apparently much lower.

4. The results showed that for methionine, digestibility values are a fair measure of the availability. In heat-damaged soya-bean-protein isolate however, digestibility of lysine over-estimated the availability, indicating that amino acid digestibility may sometimes provide a misleading indication of nutritional value.

The primary objective in the present study was to evaluate digestibility as determined in the 'ileal' analysis procedure of Varnish \& Carpenter (1975), as a measure of the biological availability of amino acids. The test materials used were a soya-bean-protein isolate, unheated (as purchased) and heat-damaged by autoclaving, and wheat and barley. Because of the low concentrations of amino acids in cereals they are difficult to assay in animal growth tests and the results may be influenced by constituents other than amino acids. Nevertheless the values for availability that have been reported have generally been low. The 'ileal' digestibility technique was applied to these cereals to determine whether this 'unavailability' could be explained by poor digestibility.

\section{EXPERIMENTAL}

\section{Test materials}

Soya-bean-protein isolate. Isolated soya-bean protein (Assay Protein C-I; Skidmore Sales and Distributing Company Inc., Cincinnati, Ohio, USA) was used $(a)$ untreated, $(b)$ steamed and $(c)$ autoclaved. For each of the treatments a layer of soya-bean protein $10 \mathrm{~mm}$ deep was placed in stainless-steel trays. For autoclaving, the protein was covered with aluminium foil so as to prevent 'dripping'. The 'steamed' protein was heated in flowing steam for $30 \mathrm{~min}$, and the 'autoclaved' protein was autoclaved in steam at $12 \mathrm{I}^{\circ}$ for $18 \mathrm{~h}$. The preparations were allowed to cool to room temperature and ground to pass through a 40 mesh sieve (aperture size $0.42 \mathrm{~mm}$ ).

* Some of these results have been reported in a preliminary communication (Amadi \& Hewitt, 1975).

$\dagger$ Formerly S. C. Amadi; present address: School of Agriculture, College of Science and Technology, PMB 5080, Port Harcourt, Nigeria. 
Wheat. Three batches of wheat were used, a commercial feed grade (wheat A), Kleiber (a spring-sown, hard wheat; wheat B), and Champlein (a winter-sown, soft wheat; wheat C).

Barley. This was a commercial feed grade barley.

\section{Experimental animals}

Chicks. The chicks used were broiler cockerels (Ross, purchased when I-d-old from Welford Hatcheries Ltd, Oxford).

Rats. Weanling male rats, $2 \mathrm{I}$-d-old, from the Institute colony of Norwegian strain rats were used.

\section{Diets}

The composition of the unsupplemented experimental diets is given in Table I except that choline and inositol were omitted from the formulations used in the first lysine bioassay with chicks. For the bioassays, two levels of each test material and three levels of the appropriate pure amino acid standard (lysine or methionine) were included at the expense of maize starch. The lysine (or methionine) contents of the test supplements were generally equivalent to the two lower levels of the standard. Exceptions were the cereals, which contained too little lysine to allow this and so their upper levels were determined by the amount of maize starch in the diet available for replacement, and autoclaved soya-bean-protein isolate which was included at double these levels because the digestibility of the protein was only 0.48 (vide infra). The actual amounts $(\mathrm{g} / \mathrm{kg}$ diet) used in the lysine bioassays were, for chicks: standard L-lysine hydrochloride, I, 2 and 3 ; untreated soya-bean protein, 14.7 and $29^{\circ} 4$; heated soya-bean protein, 29.4 and 58.8 ; cereals, 180 and 360 ; and for rats: L-lysine hydrochloride, $\mathrm{I} \cdot 5,3$ and $4 \cdot 5$; untreated soya-bean-protein isolate, 26 and 52 ; heated soyabean-protein isolate, 52 and 104 . Two other test materials were included in the rat assay and results for these were included in the statistical analysis though they are not reported here. For the methionine bioassays, all done with chicks, the quantities of supplements $(\mathrm{g} / \mathrm{kg}$ diet) were: standard DL-methionine, $0.2,0.4$ and 0.6 ; untreated and steamed soyabean-protein isolate, 22 and 44 ; autoclaved soya-bean-protein isolate, 44 and 88 ; wheats, 86.9 and 173.8 ; barley II 5 and 230 . In the digestibility experiments the soya-bean-protein isolate supplied $200 \mathrm{~g}$ crude protein (nitrogen $\times 6 \cdot 25$ ) $/ \mathrm{kg}$. The rate of inclusion of the cereals was $875 \mathrm{~g} / \mathrm{kg}$ diet.

\section{Biological tests}

Assays for available methionine and lysine with chicks. These were carried out broadly as described by Carpenter et al.(1972). The assays were conducted in two twelve-cage brooders. Diets were allocated to the cages according to randomized block designs, the 'blocks' being the brooders. Thus two cages each containing ten chicks were assigned to each diet.

The chicks were raised to $10-\mathrm{d}$-old on a nutritionally-adequate diet based on maize meal and soya-bean meal. At Io d the lightest and the heaviest chicks, approximately $40 \%$ of the total, were discarded, and the remainder divided into two groups containing equal numbers of 'light' and 'heavy' chicks, respectively. The 'light' chicks were allocated at random to the cages of one brooder, and the 'heavier' chicks to the other. The experimental diets and water were given $a d$ lib. for $8 \mathrm{~d}$.

Assay for available lysine with rats. The method of Bjarnason \& Carpenter (1969) was used with slight modifications. The assay was carried out using thirty-two cages in a battery unit with one male and one female rat per cage. The eight diets were allocated at random to the cages. 
Table $\mathrm{r}$. Composition $(\mathrm{g})$ of the basal diets used in the determination of the biological availability of lysine and methionine and in the digestibility of amino acids

\begin{tabular}{|c|c|c|c|c|}
\hline \multirow[t]{2}{*}{ Assay $\quad \ldots$} & \multicolumn{3}{|c|}{ Availability } & \multirow{3}{*}{$\begin{array}{l}\text { Digestibilit } \\
\text { Chickens }\end{array}$} \\
\hline & \multicolumn{2}{|c|}{ For lysine } & \multirow{2}{*}{$\begin{array}{c}\text { For } \\
\text { methionine } \\
\text { Chicks }\end{array}$} & \\
\hline Test animal $\ldots$ & Chicks & Rats & & \\
\hline Sesame meal & 495 & 90 & - & - \\
\hline Zein & - & 100 & - & - \\
\hline Wheat gluten & - & 65 & - & $一$ \\
\hline Groundnut meal & - & 二 & 400 & - \\
\hline Dried whey & 20 & - & 50 & 一 \\
\hline Skim-milk powder & - & 60 & - & - \\
\hline Potato starch & - & 100 & - & - \\
\hline Maize starch* & $372 \cdot 7$ & $468 \cdot 5$ & 455.5 & $885 \cdot 5$ \\
\hline L-cystine & - & - & 2 & - \\
\hline Glycine & - & - & 2 & - \\
\hline L-histidine & - & $2 \cdot 5$ & - & - \\
\hline L-isoleucine & - & 3 & - & - \\
\hline DL-methionine & - & 3 & - & - \\
\hline L-lysine hydrochloride & - & - & 4 & - \\
\hline L-threonine & 一 & 3 & - & - \\
\hline L. tryptophan & - & I & - & - \\
\hline L-valine & - & 4 & $\ldots$ & - \\
\hline Arachis oil & - & 50 & - & - \\
\hline Maize oil with vitamins $\dagger$ & 50 & - & 50 & 50 \\
\hline Choline chloride & $1 \cdot 5$ & - & $1 \cdot 5$ & $1 \cdot 5$ \\
\hline Inositol & I & - & I & $I$ \\
\hline B-vitamin triturate in glucose $\ddagger$ & 2 & - & 2 & 2 \\
\hline Vitamin mixture $\$$ & - & IO & - & $\ldots$ \\
\hline Salt mixture & 26.511 & $40 \%$ & $26 \cdot 511$ & $60^{* *}$ \\
\hline $\mathrm{CaCO}_{3}$ & 18 & - & $5 \cdot 5$ & - \\
\hline $\mathrm{CaHPO}_{4} .2 \mathrm{H}_{2} \mathrm{O}$ & $13 \cdot 3$ & - & - & - \\
\hline Chromic oxide bread $+\dagger$ & - & 一 & - & 10 \\
\hline
\end{tabular}

* Test materials were added at the expense of maize starch (see p. 560 ).

$\uparrow$ Providing (mg): 0.04 cholecalciferol, $10 \alpha$-tocopheryl acetate, 5 menaphthone. Rovimix $\mathrm{A}_{325}$ (Roche Products, Welwyn Garden City, Herts) was added to supply $5 \mathrm{mg}$ retinol $/ \mathrm{kg}$ diet.

$\ddagger$ Providing $(\mathrm{mg})$ : 15 calcium pantothenate, 6 riboflavin, 3 thiamin hydrochloride, 4 pyridoxine hydrochloride, 0.2 biotin, 40 nicotinic acid, $1 \cdot 5$ pteroylmonoglutamic acid. Cyanocobalamin solution, $100 \mu \mathrm{g} / \mathrm{ml}$, was added to supply $20 \mu \mathrm{g}$ cyanocobalamin $/ \mathrm{kg}$ diet.

$\S$ Providing (mg): 12 calcium pantothenate, 5 riboflavin, 4 thiamin hydrochloride, 6 pyridoxine hydrochloride, I biotin, Io nicotinic acid, 1000 choline chloride, 0.0075 cholecalciferol, $62 \cdot 5 \alpha$-tocopheryl acetate; 2 menaphthone, $1 \cdot 5$ retinol. Cyanocobalmin solution, $100 \mu \mathrm{g} / \mathrm{ml}$, was added to supply $2 \mathrm{mg}$ cyanocobalamin $/ \mathrm{kg}$ diet.

II Providing: $20 \mathrm{~g} \mathrm{CaHPO}_{4} \cdot 2 \mathrm{H}_{2} \mathrm{O}, 2.7 \mathrm{~g} \mathrm{NaCl}, 2.7 \mathrm{~g} \mathrm{MgSO}_{4} \cdot \mathrm{H}_{2} \mathrm{O}, 670 \mathrm{mg} \mathrm{FeSO} \cdot .7 \mathrm{H}_{2} \mathrm{O}, 270 \mathrm{mg} \mathrm{MnSO}$. ${ }_{4} \mathrm{H}_{2} \mathrm{O}$, $130 \mathrm{mg} \mathrm{ZnSO}{ }_{4} .7 \mathrm{H}_{2} \mathrm{O}$, $16 \mathrm{mg} \mathrm{CuSO} .5 \mathrm{H}_{2} \mathrm{O}, 37 \mathrm{mg} \mathrm{KI}$.

Tf Providing: $2.4 \mathrm{~g} \mathrm{CaCO}_{3}$, It $\cdot 2 \mathrm{~g}$ calcium citrate, $8 \mathrm{~g} \mathrm{Ca}\left(\mathrm{H}_{2} \mathrm{PO}_{4}\right)_{2} \cdot \mathrm{H}_{2} \mathrm{O}$, $220 \mathrm{mg}$ ferric ammonium citrate, $800 \mathrm{mg} \mathrm{MgCO} 3,880 \mathrm{mg} \mathrm{MgSO} 4 . \mathrm{H}_{2} \mathrm{O}, 100 \mathrm{mg} \mathrm{MnSO}, 7.2 \mathrm{~g} \mathrm{KCL}, 6.6 \mathrm{~g} \mathrm{Na}_{2} \mathrm{HPO}_{4}, 90 \mu \mathrm{g} \mathrm{AlNH}_{4}\left(\mathrm{SO}_{4}\right)_{2}$. ${ }_{12} \mathrm{H}_{2} \mathrm{O}, 400 \mu \mathrm{g} \mathrm{CuSO}_{4} .5 \mathrm{H}_{2} \mathrm{O}, 2 \mathrm{I} \mu \mathrm{g} \mathrm{KIO}_{3}, 17.7 \mu \mathrm{g} \mathrm{NaF}, 460 \mu \mathrm{g} \mathrm{ZnSO}_{4}, 4.7 \mu \mathrm{g} \mathrm{Na}_{2} \mathrm{~B}_{4} \mathrm{O}_{7} \cdot \mathrm{IOH}_{2} \mathrm{O}$. I.5 $\mu \mathrm{g}$ $\left(\mathrm{NH}_{4}\right)_{6} \mathrm{Mo}_{7} \mathrm{O}_{24} \cdot 4 \mathrm{H}_{2} \mathrm{O}, \mathrm{I} \cdot 8 \mu \mathrm{g} \mathrm{Na}_{2} \mathrm{SeO}_{3}$.

** As $\|$ but providing $17 \cdot 1 \mathrm{~g} \mathrm{CaHPO}_{4}, 2 \mathrm{H}_{2} \mathrm{O}$, $17 \cdot 1 \mathrm{~g} \mathrm{CaCO}_{3}, 13 \cdot 3 \mathrm{~g} \mathrm{KH}_{2} \mathrm{PO}_{4}, 8 \cdot 7 \mathrm{~g} \mathrm{NaCl}$.

†† Prepared from a mixture of $300 \mathrm{~g} \mathrm{Cr}_{2} \mathrm{O}_{3}$, I000 $\mathrm{g}$ maize starch and water. This was baked and then milled to a fine powder.

Weanling rats were given the basal (unsupplemented) diet for $5 \mathrm{~d}$. Animals weighing from 80 to $106 \mathrm{~g}$ were then given the experimental diets and water ad lib. for Io d.

Digestibility determinations. Amino acid and crude protein digestibilities were determined according to the method of Varnish \& Carpenter (1975) except that when cereals were tested lower concentrations of dietary protein were used. The chickens were raised to 
6-8 weeks of age on the 'adequate' diet. For $4 \mathrm{~d}$ access to the diet was then restricted to from 09.00 to II.00 hours and from I5.00 to 17.00 hours. During the next $2 \mathrm{~d}$ the $\mathrm{N}$-free diet (without chromium bread) was offered. It was found that the chickens consumed at least $25 \mathrm{~g}$ food in a meal. On the day of experiment the chickens were offered this quantity of $\mathrm{N}$-free diet or one of the experimental diets. After $3 \mathrm{~h}$ the birds were killed by injection of approximately $2 \mathrm{ml} \mathrm{Nembutal}$ (Abbot Laboratories Ltd, Queenborough, Kent) into the heart. The ileum, from Meckel's diverticulum to $40 \mathrm{~mm}$ proximal to the ileo-caecal junction, was quickly dissected out and the contents expressed by gentle manipulation into a plastic bottle in which they were stored at $-20^{\circ}$.

Digestibility coefficients for crude protein and amino acids were calculated using the relationship: digestibility coefficient $=I-(b+c) / a$, where $a, b$ and $c$ are the weights of $\mathrm{N}$ or amino acid per unit weight chromic oxide in the test diet, in ileal digesta from chicken given test diet and in ileal digesta from chicken given protein-free diet respectively.

For the soya-bean-protein isolate (Expt I), for barley and wheat A (Expt 2), and for wheats B and C, (Expt 3), six, two and three pairs of chickens were used respectively for each test material. Ileal digesta from each pair of chickens were pooled for analysis.

\section{Microbiological assay}

Assay for available methionine. Streptococcus zymogenes was used as test organism in the assay procedure of Ford (1962, 1964), modified in that a higher concentration of papain was used for pre-digesting the samples (Miller et al. 1965) and a composite amino acid standard was used (Ford \& Salter, I966).

\section{Chemical analysis}

Reactive lysine. The 'direct' method of Carpenter ( 1960 ) was used, based on the reaction of fluorodinitrobenzene (FDNB) with free amino groups. Recoveries were determined as described by Roach et al. (1967).

Amino acids. Samples of the test materials containing approximately $\mathrm{O} \cdot \mathrm{I} g \mathrm{~N}$ were heated with 0.116 M-hydrochloric acid under reflux in an oil bath at $12 \mathrm{I}^{\circ}$ for $24 \mathrm{~h}$. The amino acid composition of the hydrolysates was determined by ion-exchange chromatography based on the method of Spackman et al. (1958) using an automatic amino acid analyser (Model JCL-5AH; Japan Electron Optics Laboratory Co. Ltd, Tokyo, Japan).

Methionine and cystine values were based on analyses of hydrolysates prepared after performic acid treatment of the samples (Moore, 1963).

Total $N$. Samples were digested with a sulphuric acid-potassium sulphate-mercuric oxide mixture as recommended by Fleck \& Munro (1965) and the ammonia in the digests was determined colorimetrically using an Auto-Analyzer (Technicon Instruments Co. Ltd, Basingstoke, Hants) as described by Smith \& McAllan (1970).

Chromic oxide. $\mathrm{Cr}_{2} \mathrm{O}_{3}$ was determined using the procedure of Hill \& Anderson (1958) modified by Czarnocki et al. (196I) and C. K. Milner (unpublished results) broadly as described by Varnish \& Carpenter (1975).

Trypsin-inhibitor activity. Trypsin inhibitor in untreated and steamed soya-bean-protein isolate was assessed by the method of Kakade et al. (1974). One unit of trypsin inhibitor activity (TUI) is defined as the inhibition of one trypsin unit which is arbitrarily defined as an increase of $0.0 \mathrm{r}$ absorbance units at $4 \mathrm{IO} \mathrm{nm}$ of the solution of substrate benzoyl-DLarginine-p-nitroanilide.

\section{Statistical analysis}

Digestibility determinations. Within each experiment the values for each amino acid and for $\mathrm{N}$ were subjected to analysis of variance. Mean values for digestibility coefficients are 
presented with standard errors based on the pooled variation between pairs of chickens within diets.

Biological assays of lysine and methionine. In each assay the values for weight gain and food conversion efficiency (FCE; weight gain/food consumption) were subjected to analysis of variance and the variation between diets was partitioned into variation due to regression and deviations from regression. Estimates of residual variation were based on the 'blocks $x$ diets' interaction in the chick assays with eight or ten degrees of freedom and on variation between cages within diets in the rat assay with thirty-three degrees of freedom.

In some experiments there was evidence of curvature in the response to the standard amino acid supplements apparently due to reduced response to the highest concentration of standard and so the results for this concentration were excluded from the analyses. Amino acid potencies were estimated as described by Finney (1964). In all instances but two the statistical tests of assay validity were satisfactory. In the first chick assay for methionine the 'intersection' component was significant, apparently due to the results for untreated soya-bean-protein isolate. The results were therefore re-analysed excluding the values for this material. The results for untreated soya-bean-protein isolate in the third methionine assay are also excluded since an error in diet formulation was suspected. In the second lysine bioassay with chicks there was a significant 'blanks' component for the weight-gain values. Potencies were therefore estimated treating the basal diet as one level of a hypothetical test substance.

The various FCE-based potency estimates were combined using the methods described by Finney (1964). Results with approximate standard errors are given in Table 6.

\section{RESULTS}

\section{Amino acid composition}

Autoclaving reduced the crude protein content of the soya-bean-protein isolate from 900 to $830 \mathrm{~g} / \mathrm{kg}$ dry matter but the concentrations of most amino acids in the protein $(\mathrm{g} / \mathrm{kg}$ crude protein) (Table 2 ) were only slightly affected. Cystine was reduced by $32 \%$ however, and there were also small reductions (from 5 to II \%) in valine, threonine, aspartic acid and isoleucine.

\section{Digestibility of amino acids and crude protein}

Digestibility coefficients of amino acids in the test materials, based on analyses of the contents of the lower ileum, are given in Table 3. Amino acids in the unheated soya-beanprotein isolate were well digested with an average coefficient of 0.93 . Autoclaving reduced digestibilities by approximately half, but lysine, aspartic acid and glutamic acid gave marginally the lowest values.

Amino acids in all four cereal samples were well digested. There were small but consistent differences between amino acids. Methionine, glutamic acid and proline were digested to the greatest extent while lysine, histidine, aspartic acid, threonine, serine, glycine and alanine were slightly less well digested. There was little difference between wheat and barley for any of the amino acids.

There was general agreement between the digestibility coefficients for crude protein, also given in Table 3, and the average digestibilities for all the amino acids. The value for barley was slightly lower than those for the three wheats, but it was accompanied by considerable variation between duplicate measurements. 
Table 2. Concentrations of amino acids $(\mathrm{g} / \mathrm{kg}$ crude protein (nitrogen $\times 6 \cdot 25)$ ) and crude protein $(\mathrm{g} / \mathrm{kg}$ dry matter) in test materials

(Each value is a mean of four determinations)

\begin{tabular}{|c|c|c|c|c|c|c|}
\hline & Soya-ber & an protein & & Wheats & & \\
\hline & Untreated & Autoclaved & A & B & $\mathrm{C}$ & Barley \\
\hline Lysine & $6 I \cdot 4$ & $59 \cdot 3$ & $27 \cdot 1$ & $27 \cdot 2$ & $26 \cdot 8$ & $3 \mathrm{I} \cdot 5$ \\
\hline Histidine & $26 \cdot 8$ & $26 \cdot 2$ & $25 \cdot 2$ & $23 \cdot 3$ & $2 \mathrm{I} \cdot \mathrm{I}$ & $20 \cdot 8$ \\
\hline Arginine & 90.9 & $89 \cdot 3$ & $52 \cdot 8$ & $54 \cdot 3$ & $52 \cdot 0$ & $50 \cdot 9$ \\
\hline Aspartic acid & I $27 \cdot 4$ & $120 \cdot 5$ & $53 \cdot 3$ & $5 \mathrm{I} \cdot 7$ & 57.0 & $56 \cdot 2$ \\
\hline Threonine & $42 \cdot 6$ & 38.9 & $3 I \cdot 5$ & $34 \cdot 1$ & $33 \cdot I$ & $31 \cdot 8$ \\
\hline Serine & $60 \cdot 9$ & $60 \cdot 8$ & $45 \cdot 3$ & $52 \cdot 3$ & $55 \cdot I$ & $36 \cdot 8$ \\
\hline Glutamic acid & $207 \cdot I$ & $208 \cdot 6$ & $284 \cdot 5$ & 313.0 & $326 \cdot 3$ & 202.4 \\
\hline Proline & $56 \cdot 3$ & $54 \cdot 4$ & $94 \cdot 1$ & 103.9 & 105.5 & 113.9 \\
\hline Glycine & $43 \cdot 4$ & $44^{\circ} \mathrm{O}$ & $37 \cdot 8$ & $44 \cdot 4$ & $46 \cdot 9$ & $39 \cdot 2$ \\
\hline Alanine & 44.0 & $44^{\circ} 0$ & $35 \cdot 5$ & $37 \cdot 3$ & $40 \cdot 3$ & 38.0 \\
\hline Cystine & II 4 & $7 \cdot 7$ & $22 \cdot 7$ & $24 \cdot 3$ & $26 \cdot 7$ & $19 \cdot 7$ \\
\hline Valine & $51 \cdot 7$ & $46 \cdot I$ & $48 \cdot 0$ & $42 \cdot 9$ & $43 \cdot 5$ & 49.0 \\
\hline Methionine & 12.0 & I $2 \cdot I$ & 17.5 & $15 \cdot 1$ & 16.6 & $17 \cdot 1$ \\
\hline Isoleucine & $54 \cdot 8$ & $51 \cdot 9$ & $33 \cdot 4$ & $35 \cdot 6$ & $37 \cdot 4$ & 340 \\
\hline Leucine & $86 \cdot 6$ & $85 \cdot 8$ & $66 \cdot 5$ & $73 \cdot 3$ & $76 \cdot 5$ & $69 \cdot 2$ \\
\hline Tyrosine & 35.0 & $34 \cdot 8$ & $3 I \cdot 2$ & $33 \cdot 1$ & 33.5 & $32 \cdot 2$ \\
\hline Phenylalanine & 619 & $6 I \cdot 4$ & $48 \cdot 8$ & $45 \cdot 7$ & $59 \cdot 0$ & $50 \cdot 5$ \\
\hline Crude protein & 900 & 830 & I 34 & I 34 & 125 & 106 \\
\hline
\end{tabular}

Table 3. Digestibility coefficients for amino acids and crude protein (nitrogen $\times 6.25)$ in test materials, based on the composition of digesta in the lower ileum of chickens

(Values are based on analysis of pooled samples of digesta, a pair of chickens contributing to each pool: soya-bean proteins, six samples each; barley and wheat A, two samples each; wheats $B$ and $C$, three samples each)

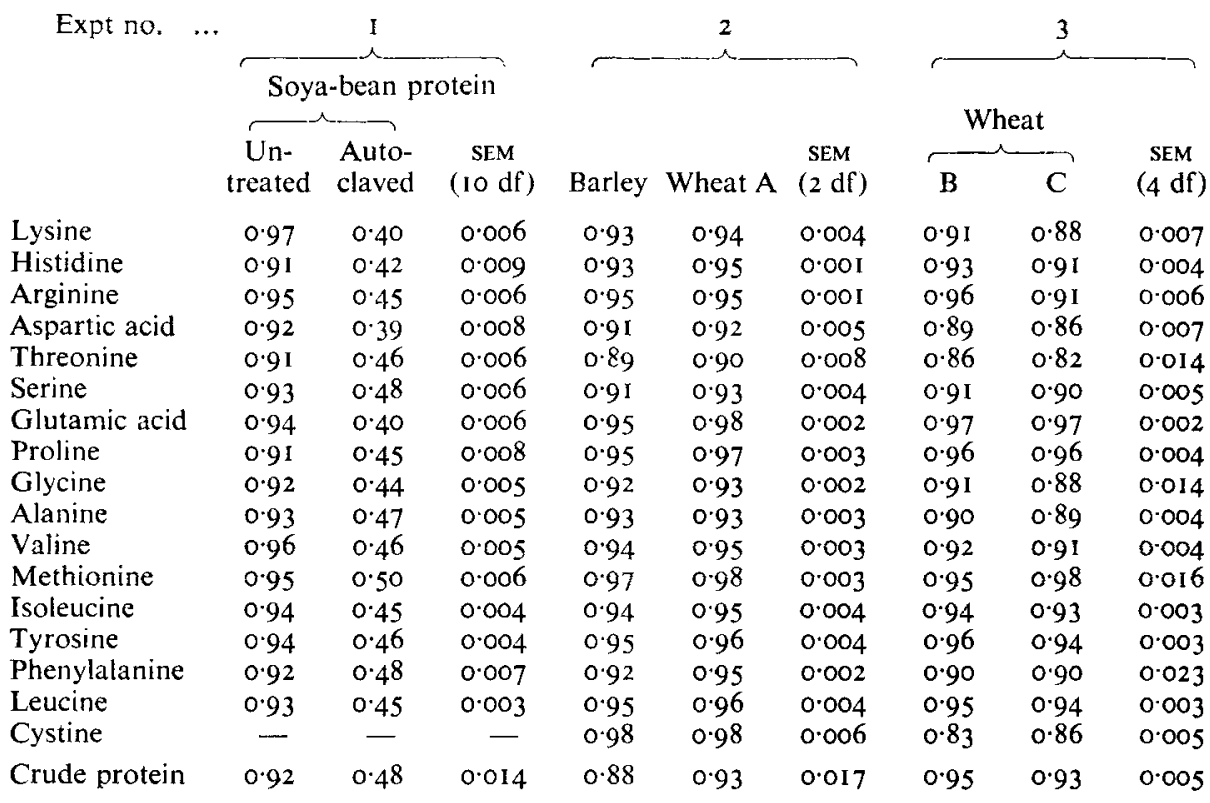




\section{Biological availability of amino acids}

The results of the biological assays are given in Tables 4 (lysine) and 5 (methionine). On average the precision of the potency estimates though low was of a similar magnitude to that found by Carpenter et al. (1972) in a collaborative study of the methionine bioassay involving six laboratories. The rat assay values were rather more precise while the FCE values from the second methionine bioassay gave less precise results than the other assays. Repetitions of the assays gave quite precise pooled estimates of potency (Table 6). The potency of lysine in the untreated and in the autoclaved soya-bean-protein isolate tended to be higher when based on FCE values than when based on weight-gain results. The opposite was observed for wheat and barley. There was no consistent difference between FCE- and weight gain-based potencies in the methionine bioassays. Since availabilities based on weight gains might be affected by stimulation or depression of food intake by the test materials the values based on FCE were regarded as being more closely related to protein quality, and it is with these latter values that the discussion will be concerned henceforward. For convenience biological availabilities, that is pooled averages of the FCEbased potencies from the separate biological assays, are compiled with the other results in Table 6.

The availability of lysine in the soya-bean-protein isolate was severely depressed by the heat treatment, from 0.95 to 0.29 of the corresponding values for total lysine. A smaller effect was found for methionine, the availability of which was reduced from 0.83 to 0.55 .

The results for the cereals indicated that the availability of lysine in barley was 0.88 of the total, as against values of 0.67 and 0.70 in wheat. Methionine appeared to be highly available in wheat and barley though for the latter the individual results were somewhat inconsistent.

\section{In vitro assays for available methionine and lysine in soya-bean-protein isolate}

According to the microbiological assay the availability of methionine in the untreated protein isolate was approximately 0.8 of the total (Table 6). Autoclaving reduced this to approximately half.

The FDNB-reactive-lysine in untreated soya-bean-protein isolate represented 0.98 of total lysine. Autoclaving reduced this value to 0.44 . The recoveries of $\epsilon$-dinitrophenyl lysine in the presence of unheated and autoclaved isolate were 0.90 and 0.82 .

Trypsin inhibitor content of the soya-bean-protein isolate

The untreated isolate contained very little trypsin inhibitor: $2 \cdot 3 \mathrm{TUI} / \mathrm{mg}$. For comparison a preparation of soya-bean protein that contained most of the inhibitor from the original meal contained $90.6 \mathrm{TUI} / \mathrm{mg}$. After steaming no inhibitor was detected.

\section{DISCUSSION}

In most foods the biological availability of the amino acids is primarily determined by the over-all digestibility of the protein. As well as this however, there may be differences in digestibility between the amino acids within a protein and the measurement of individual amino acid digestibilities may therefore be justified. In considering the nutritional quality of proteins the main interest will be the amounts and biological availabilities of specific amino acids. If the digestibility of an amino acid determines its availability then the former will be a satisfactory measure of the latter and there will be no need to measure availabilities. The validity of this hypothesis was investigated in the work described. Amongst the test materials studied was a soya-bean-protein isolate, an example of the type of product 
Table 4 . Contents of available lysine $(\mathrm{g} / \mathrm{kg}$ crude protein; nitrogen $\times 6.25)$ in test materials as determined in chick and rat assays

(Values are potency estimates (Finney, 1964) with, in parentheses, $95 \%$ fiducial limits)

(a) Values based on 'wt-gain' results

Test animal
Assay no.
Soya-bean protein:
Untreated
Autoclaved
Wheats:
A
B
C

Barley

Test animal

Assay no. ...

Soya-bean protein: Untreated

Autoclaved

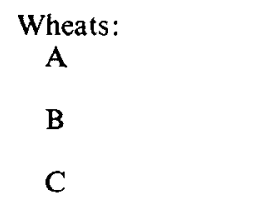

Barley

\begin{tabular}{ccc} 
& \multicolumn{3}{c}{ Chick } & 3 \\
1 & 2 & - \\
$58 \cdot 5$ & $52 \cdot 1$ & - \\
$(44 \cdot 4,72 \cdot 7)$ & $(40 \cdot 0,64 \cdot 3)$ & $12 \cdot 4$ \\
$15 \cdot 3$ & $(5 \cdot 7,19 \cdot 1)$ & \\
$(8 \cdot 6,22 \cdot 0)$ & $13 \cdot 4$ & $19 \cdot 2$ \\
$23 \cdot 3$ & $(6 \cdot 7,19 \cdot 9)$ & $(14 \cdot 2,24 \cdot 3)$ \\
$(16 \cdot 3,30 \cdot 4)$ & - & $20 \cdot 5$ \\
- & - & $(15 \cdot 4,25 \cdot 6)$ \\
- & & $26 \cdot 4$ \\
& & $(20 \cdot 7,32 \cdot 0)$
\end{tabular}

$\begin{array}{cc}35 \cdot 4 & 30 \cdot I \\ (26 \cdot I, 44 \cdot 8) & (22 \cdot 0,38 \cdot 3)\end{array}$

(b) Values based on food conversion efficiency* results

\begin{tabular}{|c|c|c|c|}
\hline \multicolumn{3}{|c|}{ Chick } & \multirow[t]{2}{*}{ Rat } \\
\hline I & 2 & 3 & \\
\hline $\begin{array}{c}58 \cdot 7 \\
(40 \cdot 3,77 \cdot 2)\end{array}$ & $\begin{array}{c}65 \cdot 0 \\
(45 \cdot 0,85 \cdot 0)\end{array}$ & - & $\begin{array}{c}55 \cdot 3 \\
(48 \cdot 2,62 \cdot 4)\end{array}$ \\
\hline $\begin{array}{c}21 \cdot 0 \\
(12 \cdot 1,29 \cdot 9)\end{array}$ & $\begin{array}{c}17 \cdot 1 \\
(8 \cdot 2,26 \cdot 1)\end{array}$ & - & $\begin{array}{c}14.4 \\
(1 \mathrm{I} \cdot 2,17 \cdot 5)\end{array}$ \\
\hline $\begin{array}{c}22 \cdot 0 \\
(13 \cdot 0,31 \cdot I)\end{array}$ & $\begin{array}{c}17 \cdot 5 \\
(8 \cdot 5,26 \cdot 5)\end{array}$ & $\begin{array}{c}15 \cdot 7 \\
(5 \cdot 2,25 \cdot 8)\end{array}$ & - \\
\hline- & - & $\begin{array}{c}17 \cdot 8 \\
(7 \cdot 7,28 \cdot 3)\end{array}$ & 一 \\
\hline - & - & $\begin{array}{c}18 \cdot 6 \\
(7 \cdot 6,29 \cdot 7)\end{array}$ & - \\
\hline $\begin{array}{c}29 \cdot 7 \\
(18 \cdot 2,41 \cdot 3)\end{array}$ & $\begin{array}{c}26 \cdot I \\
(14 \cdot 5,37 \cdot 7)\end{array}$ & - & - \\
\hline
\end{tabular}

which is now in widespread use to replace or 'extend' animal protein in manufactured 'meat' products. The effect of severe heating (autoclaving) on such a protein was examined. Wheat and barley were also included because they can be important sources of protein for man and non-ruminant farm animals and because there have been several reports that amino acids in some cereals are not fully available (e.g. Gupta et al. 1958; Calhoun et al. 1960; Hepburn et al. 1966).

In the work described 'ileal' digestibilities were measured by the method of Varnish \& Carpenter (1975) and the values for lysine and methionine compared with standard biological measures of amino acid availabilities. The 'ileal analysis' method has the advantage over methods involving faecal analysis (e.g. Kuiken \& Lyman, I948) in that bacterial modification of digesta residues in the lower gut does not influence the results. The method wa: quite precise. Relatively small amounts of test materials were required and since the chickens consumed equal quantities of food the experimental conditions were clearly defined. This was not the situation with the biological assays of available amino acids in which diets were offered ad lib. and variation in food intake could affect the results. Carpenter 
Table 5. Contents of available methionine $(\mathrm{g} / \mathrm{kg}$ crude protein, nitrogen $\times 6.25)$ in test materials as determined in four chick assays

(Values are potency estimates based on slope ratio analyses (Finney, 1964) with, in parentheses, $95 \%$ fiducial limits)

(a) Values based on 'wt-gain' results

Assay no. ...

Soya-bean protein:

Untreated

Steamed

Autoclaved

I
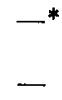

Wheat A

Barley

Assay no. ...

Soya-bean protein:

Untreated

Steamed

Autoclaved

Wheat A

Barley

$5 \cdot 1$
$(4 \cdot 3,5 \cdot 9)$
$14 \cdot 0$
$(11 \cdot 5,16 \cdot 6)$
$14 \cdot 8$
$(12 \cdot 4,17 \cdot 3)$

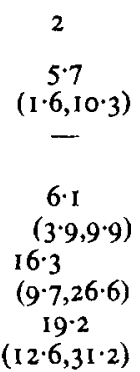

4

10.9

$(7 \cdot 2,16 \cdot 8)$

$9 \cdot \mathrm{I}$

$(5 \cdot 6,14 \cdot 4)$

8.2

$(5 \cdot 8,12 \cdot 6)$

21.8

(I $5 \cdot 3,33 \cdot 6$ )

(b) Values based on food conversion efficiency $\ddagger$ results

$(8 \cdot 6,21 \cdot 1) \quad(13 \cdot 6,50 \cdot 8)$

3

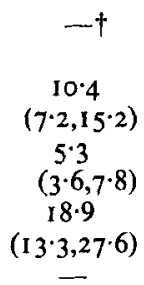

$9 \cdot 2$

$(6 \cdot 3,13 \cdot 2)$

$9 \cdot 1$

$(6 \cdot 2,13 \cdot 0)$

$7 \cdot 2$

$(5 \cdot 4,10 \cdot 0)$

$17 \cdot 0$

$\left(12 \cdot 2,24^{\circ} 0\right)$

* Results for untreated soya-bean protein excluded since they appeared to cause a significant intersection mean square.

$\dagger$ Results for untreated soya-bean protein excluded due to a diet formulation error.

$\ddagger W t$ gain/food consumed.

et al. (1972) reported that values based on FCE were 13\% higher than those based on weight gain and concluded that the former were to be preferred since effects of test materials on food intake would have less influence on potencies based on FCE results.

In the assays of biological availability the graded supplements of test materials increased the amount of protein in the diet and this may have affected our potency estimates. In the lysine bioassays the higher supplements of untreated and autoclaved soya-bean-protein isolate supplied 26 and $49 \mathrm{~g}$ crude protein $/ \mathrm{kg}$ respectively in the chick experiments and 47 and $86 \mathrm{~g} / \mathrm{kg}$ in the rat experiments. Miller et al. (1965) showed that the addition of a protein devoid of sulphur amino acids at a level of $54 \mathrm{~g} / \mathrm{kg}$ depressed the growth response to methionine supplements, and so the possibility was considered that the increase in dietary protein in our work resulted in the underestimation of potencies. There was no indication of a 'protein' effect in the results for the available lysine of untreated soya-beanprotein isolate which on average was only a little less than the total content (Table 6). The same should apply to the results for the autoclaved material since the conditions of assay were similar, inasmuch as the supplements of autoclaved isolate contained approximately the same amounts of digestible protein as the unheated (cf. the ileal digestibility coefficients, Table 3). Confirmation of the results was obtained in an experiment (Achinewhu, unpublished results) in which the test materials were added on the basis of their crude protein content to supply up to $48 \mathrm{~g}$ protein $/ \mathrm{kg}$. Some difficulties were encountered with the autoclaved material because of its low potency but the estimates of available lysine of 16 and $57 \mathrm{~g} / \mathrm{kg}$ 


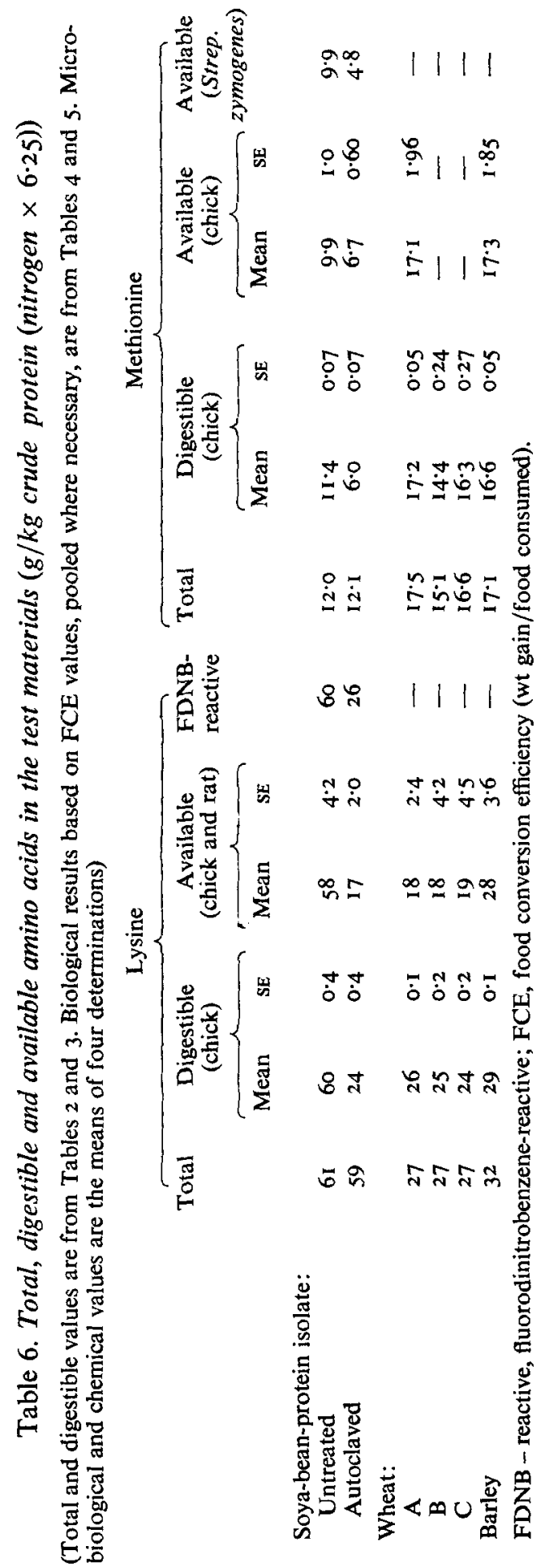


protein for autoclaved and untreated soya-bean-protein isolate respectively were in agreement with the present findings.

Soya-bean-protein isolate: the effect of autoclaving. The amino acids in the untreated soya-bean-protein isolate were highly digestible and the lysine present was fully available (Table 6). The availability of methionine was on average somewhat less than its digestibility $(P>0.05)$. Steaming, which would destroy any of the soya-bean anti-nutritional factors present in the isolate did not affect the availability of methionine (Table 5).

Autoclaving had little effect on the total amino acid composition $(\mathrm{g} / \mathrm{kg}$ crude protein) of the soya-bean-protein isolate, except that cystine was reduced, though crude protein decreased by $8 \%$ (Table 2 ). Loss of cystine and of some $\mathrm{N}$ when animal proteins are severely heated has been reported by Donoso et al. (1962) and Varnish \& Carpenter (1975).

In general autoclaving reduced the digestibility of amino acids by approximately half though that of lysine was reduced by $60 \%$. The results for available methionine in the autoclaved isolate were rather variable ranging from 5.3 to $8.6 \mathrm{~g} / \mathrm{kg}$ protein and averaging $6.7 \mathrm{~g} / \mathrm{kg}$. Thus the available methionine apparently exceeded the amount digested $(P>0.05)$, but the results for the former were too erratic to conclude that either method was in error. The results suggest that digested methionine is fully available. The microbiological results were in general agreement with the 'chick-available' values in showing that autoclaving reduced availability by approximately half. In absolute terms the value for unheated material was equal to the 'chick' value whilst that for heated material was less.

The effect of heat treatment of the soya-bean-protein isolate on the biological availability of lysine was not fully evident in the chemical (FDNB) measure of availability, the latter being slightly greater than the amount of digestible lysine. Nonetheless it is clear that the amount of lysine available biologically was less than the amount that was digested $(P<0.001)$. Others have shown that the digestibility of lysine is more susceptible to heatdamage than is that of methionine. Varnish \& Carpenter (1975) showed that autoclaving chicken muscle at $1 \mathrm{I}^{\circ}$ for $27 \mathrm{~h}$ reduced the digestibilities of lysine and methionine to 0.52 and 0.62 of the corresponding values for untreated muscle. Erbersdobler \& Riedel (1972) also found that lysine was more severely affected by moist heat treatment than was methionine. Digestibility of the latter for the chick, as determined by faecal analysis, was reduced from approximately 0.9 to 0.5 while lysine digestibility was reduced to approximately 0.3 . Varnish \& Carpenter (I975) found that amino acid availabilities were reduced by their heat treatment to the same extent as digestibilities and they concluded that the effect of heating could be fully accounted for by the reduced digestibility. In the present work this is possibly true for methionine but not for lysine. Heating the soya-bean protein under our conditions ( $120^{\circ}$ for $18 \mathrm{~h}$ ) had a more severe general effect on digestibility than that reported by Varnish \& Carpenter (1975) though the relative effects on lysine and methionine were similar. However, the reduced digestibility of lysine did not fully account for the reduction in biological availability.

The difference in findings may be explained by the different types of material used. Varnish \& Carpenter (I975) used an animal protein (chicken muscle) whereas we used a vegetable protein which according to the manufacturer contained approximately $25 \mathrm{~g}$ carbohydrate $/ \mathrm{kg}$. Amadi (I975) found that hydrolysates of the urine of rats given autoclaved (but not untreated) protein isolate contained furosine, a derivative of fructoselysine, suggesting that fructose-lysine, which is not utilized by the rat, was formed during the heat treatment. This could account for incomplete utilization of lysine absorbed from the autoclaved soya-bean-protein isolate. Another possibility is that during the heating carbohydrate and protein react together (Maillard reaction) to form products which reduce the efficiency of protein utilization. Adrian \& Frangne (1973) showed that a model compound of an early stage of the Maillard reaction can reduce protein utilization. If this 
is a general effect it is difficult to see why the availability of lysine and methionine would not be equally affected.

Barley and wheat: amino acid digestibility and availability. In both cereals amino acid digestibilities were generally high, the three wheats and the barley giving similar values. Previous estimates of amino acid digestibilities with cereals, based on the analysis of faeces, have also generally given high values. For example, Kuiken \& Lyman (1948) reported digestibilities determined with rats of from 0.92 to 0.99 for the essential amino acids in wheat. As in the present work, lysine and histidine were at the lower end of the range whereas methionine was in the middle. In contrast to the reports showing that the amino acids in cereals are all highly digestible, McNab \& Shannon (I974), using colostomized hens, reported values of from 0.72 to 0.94 for wheat and 0.73 to 0.92 for barley though it still appeared that lysine was less digestible than methionine.

In the work reported in this paper the availability of lysine in wheat, based on FCE results, was only approximately 0.68 of the total content whereas the value for methionine was 0.98 . This difference cannot be explained by the digestibility coefficients of these two amino acids which were $0.9 \mathrm{I}$ and 0.97 respectively. Comparison of the availability results with the digestibility values should be made with caution however, since they were determined at different concentrations of dietary protein $(200 \mathrm{~g} / \mathrm{kg}$ plus the protein from the test materials in the availability experiments; approximately $105 \mathrm{~g} / \mathrm{kg}$ in the digestibility experiments). Amino acid digestibilities at the two protein concentrations may differ.

The possibility that the values for available lysine were low because the wheat supplements increased dietary protein concentration might seem unlikely since the amounts of wheat protein $(24$ and $48 \mathrm{~g} / \mathrm{kg}$ ) were similar to the amounts of untreated soya-bean-protein isolate tested in the rat bioassay. However, assay conditions may affect expression of the protein effect. Wheat is a poor source of lysine and so amino acid balance would differ; this may be critical. De Muelenaere et al. (1967) considered that increasing the level of an unbalanced protein could lead to low estimates of availability. The low availability of lysine in wheat, be it apparent or real, reported by Gupta et al. (1958) and Calhoun et al. (1960) and in the present work remains to be explained. Our work would appear to exclude digestibility as the basis of an explanation.

With barley the discrepancy between lysine and methionine availability was less than with wheat: lysine availability was 0.88 and the value for methionine was greater than $\mathbf{I}$. The corresponding digestibility values were 0.93 and 0.97 .

In conclusion it appeared that digestibility was the main factor determining the availability of lysine and methionine in the untreated and autoclaved soya-bean-protein isolate although upon treatment with heat the decrease in the digestibility of lysine did not fully account for the reduction in availability. So far the ileal digestibility technique has only been applied to a few proteins and further work on a wider range of materials is needed before the method can be fully assessed. The method did not give a good measure of the availability of lysine in the heat-damaged material and in the cereals. In the latter, this may have been due to the problems in their biological assay though for methionine in cereals availability was very similar to digestibility.

The authors wish to thank Professor J. W. G. Porter and Dr J. E. Ford for their helpful advice and Mr J. E. Cockburn for the amino acid analyses. 


\section{REFERENCES}

Adrian, J. \& Frangne, R. (1973). Ann. Nutr. Alim. 27, I I I.

Amadi, S. C. (I 975). Studies on the digestion, absorption and availability of amino acids in unheated and heat damaged vegetable proteins. PhD Thesis, University of Reading.

Amadi, S. C. \& Hewitt, D. (1975). Proc. Nutr. Soc 34, 26A.

Bjarnason, J. \& Carpenter, K. J. (1969). Br. J. Nutr. 23, 859.

Calhoun, W. K., Hepburn, F. N. \& Bradley, W. B. (I960). J. Nutr. 7o, 337.

Carpenter, K. J. ( I960). Biochem. J. 77, 604.

Carpenter, K. J., McDonald, I. \& Miller, W. S. (1972). Br. J. Nutr. 27, 7.

Czarnocki, J., Sibbald, I. R. \& Evans, E. V. (I96I). Can J. Anim. Sci. 41, 167.

De Muelenaere, H. J. H., Chen, M-L. \& Harper, A. E. (1967). J. Agric. Fd Chem. 15, 310.

Donoso, G., Lewis, O. A. M., Miller, D. S. \& Payne, P. R. (1962). J. Sci. Fd Agric. 13, 192.

Erbersdobler, H. \& Riedel, G. (.1972). Arch. Geflügelk. 36, 2 I8.

Finney, D. J. (1964). Statistical Method in Biological Assay. London: Griffin.

Fleck, A. \& Munro, H. N. (1965). Clinica chim. Acta 11, 2.

Ford, J. E. (1962). Br. J. Nutr. 16, 409.

Ford, J. E. (1964). Br. J. Nutr. 18, 449.

Ford, J. E. \& Salter, D. N. (I966). Br. J. Nutr. 2o, 843.

Gupta, J. D., Dakroury, A. M., Harper, A. E. \& Elvehjem, C. A. (1958). J. Nutr. 64, 259.

Hepburn, F. N., Calhoun, W. K. \& Bradley, W. B. (I966). Cereal Chem. 43, 27 I.

Hill, F. W. \& Anderson, D. L. (1958). J. Nutr. 64, 587.

Kakade, M. L., Rackis, J. J., McGhee, J. E. \& Puski, G. (1974 ). Cereal Chem. 5r, 376.

Kuiken, K. A. \& Lyman, C. M. (I948). J. Nutr. 36, 359.

McNab, J. M. \& Shannon, D. W. F. (1974). Br. Poult. Sci. 15, 56I.

Miller, E. L., Carpenter, K. J., Morgan, C. B. \& Boyne, A. W. (1965). Br. J. Nutr. 19, 249.

Moore, S. (1963). J. biol. Chem. 238, 235.

Roach, A. G., Sanderson, P. \& Williams, D. R. (1967). J. Sci. Fd Agric. 18, 274.

Smith, R. H. \& McAllan, A. B. (I970). Br. J. Nutr. 24, 545.

Spackman, D. H., Stein, W. H. \& Moore, S. (1958). Analyt. Chem. 30, 1185.

Varnish, S. A. \& Carpenter, K. J. (I975). Br. J. Nutr. 34, 339. 